\title{
ASIAN JOURNAL OF MEDICAL SCIENCES
}

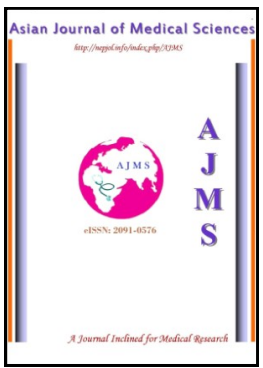

Mutation Analysis of the LDL Receptor Gene in Indian Families with Familial Hypercholesterolemia

Suyamindra Kulkarni ${ }^{1}$, Suresh Basavraj ${ }^{1}$, G S Kadakol ${ }^{1}$, Vandana $\mathrm{T}^{1}$, Amruta Markande ${ }^{1}$, Jayaraj Sindhoor ${ }^{3}$, Bhushan B Kulkarni ${ }^{2}$, S V Hiremath ${ }^{2}$, K. Thangaraj ${ }^{4}$,P B Gai ${ }^{*}$

${ }^{1}$ Research Center for DNA Diagnostics, Department of Applied Genetics, Karnatak University, Dharwad, Karnataka, India. ${ }^{2}$ Department of Biotechnology, P. C. Jabin Science College, Hubli, Karnataka, India. ${ }^{3}$ Department of Medicine, S D M Medical College, Dharwad, Karnataka, India. ${ }^{4}$ Center for Cellular and Molecular Biology (CCMB), Hyderabad, Andhra Pradesh, India.

\section{Abstract}

Objective: Familial Hypercholesterolemia $(\mathrm{FH})$ is a metabolic disorder inherited as an autosomal dominant trait characterized by an increased plasma low-density lipoprotein (LDL) level. The disease is caused by several different mutations in the LDL receptor (LDLR) gene. Several mutations have been reported in this gene in patients from several ethnic groups. Early identification of individuals carrying the defective gene could be useful in reducing the risk of atherosclerosis and myocardial infraction by the available therapeutic methods. The techniques available for determining the number of the functional LDLR molecules are difficult to carry out and expensive. Our study presents mutation analysis of the LDLR gene in 24 Indian families with $\mathrm{FH}$.

Material \& Methods: Peripheral blood samples were obtained form individuals after taking informed consent on the condition that each of these individuals had at least one first-degree relative affected with FH. Genomic DNA was isolated, exon-specific intronic primers were designed and used to amplify DNA samples from individuals.PCR products were directly subjected to automated DNA sequencing to detect the mutations. Along with the affected individuals, ten ethnically matched controls were also analyzed to determine the presence of the same mutations. Patients with Nephrotic Syndrome admitted to hospital were excluded from the study.

Results: All the 24 patients had total cholesterol level above $300 \mathrm{mg} / \mathrm{dl}$ and LDL cholesterol level above 200mg/dl. Sequence analysis of the $L D L$ receptor $(L D L R)$ gene showed 3 novel mutations which have never been reported elsewhere. In exon 10 we reported g.29372_29373insC, which was found in all the 24 patients and was missence mutation coding for $C$ (cysteine) instead of $V$ (valine).

Conclusion: Our study reported 3 novel mutations in 24 Indian families. These novel mutations are predicted to produce change in the amino acid and thus leading to the conformational changes in the structure of LDLR protein. Change in the LDLR protein makes the LDL receptor unable to transport the cholesterol in to the cell and hence cholesterol starts accumulating in the blood stream and leads to $\mathrm{FH}$.

Key Words: Familial Hypercholesterolemia; Mutation analysis; LDL Receptor gene

\section{Introduction}

A amilial hypercholesterolemia $(\mathrm{FH})$ is a disease 3949) specifying the receptor for a plasma cholesterol transport particle called Low Density Lipoprotein (LDL). In patients who inherit one or two copies of this mutant gene, the reduction in the number of LDL receptor causes LDL particles to accumulate to high levels in plasma. The elevated plasma LDL level inturn produces atherosclerosis and eventually death. ${ }^{1} \mathrm{FH}$ is a very

\section{*Correspondence:}

Dr. P B Gai, Professor \& Co-ordinator Department of Studies in Applied Genetics, Principal Investigator Research Center for DNA Diagnostics (RCDD), Principal Investigator Center of Excellence in Molecular Hemato Oncology, Karnatak University, Dharwad-580003. Email: pramodbgai@gmail.com, Phone: Office- 0836-2215350, common autosomal dominant disease with the frequency of $0.2 \%$ world wide. ${ }^{2,3}$ In India still the exact estimate of the $\mathrm{FH}$ is unknown.

Premature coronary heart disease, elevated LDL-cholesterol (LDL-C) and tendon xanthomas are the common clinical features of the $\mathrm{FH}^{2,4}$ Sometimes, in early stage of occurrence of $\mathrm{FH}$, these clinical features are absent especially in children and thus do not allow predicting $\mathrm{FH}$ in early stage. If, $\mathrm{FH}$ is diagnosed in early onset of its occurrence, it can be controlled by appropriate diet and drug treatment and thus would prevent development of coronary heart disease in future. Molecular profiling and mutation analysis of the LDLR gene would be an effective tool in diagnosis of $\mathrm{FH}$ 
especially where the clinical features are totally absent. Early identification of individuals carrying the defective gene could be useful in reducing the risk of atherosclerosis and myocardial infarction. The available techniques for identifying the number of properly working LDLR molecules are difficult and expensive too. Many studies have shown different LDLR gene polymorphisms in different ethnic groups. ${ }^{5-8}$ India is known for its diverse population and many ethnic groups, hence development of ethnic group specific biomarker would be of great importance and also cost effective.

In the present study, we report the mutations in the LDLR gene which are observed in 24 South Indian families by direct automated sequencing method.

\section{Material and Methods}

\subsection{Patient Selection}

All the patients included in this study were admitted and being treated at S.D.M. Medical college, Dharwad, Karnataka, India between 2009-2010. Plasma lipid concentrations were measured while all patients consumed their regular diet and prior to the administration of hypolipidemic drug. Total cholesterol, triglycerides and HDL-C levels were measured enzymatically with commercial kits (Span Diagnostics, India) using automated analyzer (Artos, India). LDLC cholesterol was calculated by Friedewald's formula. After conducting biochemical tests and on the condition that each of these patients had at least one first-degree relative affected with $\mathrm{FH}, 24$ patients agreed to involve in the study. Alongwith this, we also collected blood samples from 10 ethnically matched individuals who are not related to these patient's families and were absolutely normal. Detailed informed consent was obtained from all the 24 patients and controls in vernacular. $1 \mathrm{ml}$ of blood sample was collected from the patients and controls in EDTA coated vacutainer (BD, USA) stored at $-20^{\circ} \mathrm{C}$ until further process.

\subsection{Genomic DNA isolation, $P C R$ amplification and mutation analysis}

Genomic DNA was isolated from $300 \mu$ of peripheral blood samples using a commercial DNA isolation kit (Bangalore Genei, India).All the isolated DNA samples were quantified using biophotometer (Eppendorf, Germany).
Table 1: Details of the primers designed and used for the amplification of all the exons of LDLR gene

\begin{tabular}{|c|c|c|c|c|}
\hline $\begin{array}{l}\text { S } \\
\text { No. }\end{array}$ & $\begin{array}{l}\text { Exon } \\
\text { No. }\end{array}$ & Primer Sequence & $\begin{array}{l}\text { Am- } \\
\text { plicon } \\
\text { Size }\end{array}$ & $\begin{array}{l}\text { Anneal- } \\
\text { ing } \\
\text { Tem- } \\
\text { perature }\end{array}$ \\
\hline \multirow[t]{2}{*}{1} & $1 \mathrm{~F}$ & 5'-CTCCTCTTGCAGTGAGGTGA-3' & \multirow[t]{2}{*}{294} & \multirow[t]{2}{*}{59.4} \\
\hline & $1 \mathrm{R}$ & 5'-CCTCTCAACCTATTCTGGGG-3' & & \\
\hline \multirow[t]{2}{*}{2} & $2 \mathrm{~F}$ & 5'-GATTCTGGCGTTGAGAGACC-3' & \multirow[t]{2}{*}{191} & \multirow[t]{2}{*}{58.4} \\
\hline & $2 \mathrm{R}$ & 5'-ATATCATGCCCAAAGGGGAC-3' & & \\
\hline \multirow[t]{2}{*}{3} & $3 \mathrm{~F}$ & 5'-TGGGTCTTTCCTTTGAGTGA-3' & \multirow[t]{2}{*}{200} & \multirow[t]{2}{*}{56.3} \\
\hline & $3 \mathrm{R}$ & 5'-AGGCTCAATAGCAAAGGCAG-3' & & \\
\hline \multirow[t]{2}{*}{4} & $4 \mathrm{~F}$ & 5'-GACTTCACACGGTGATGGTG-3' & \multirow[t]{2}{*}{521} & \multirow[t]{2}{*}{58.4} \\
\hline & $4 \mathrm{R}$ & 5'-TCCACTTCGGCACCTAAATC-3' & & \\
\hline \multirow[t]{2}{*}{5} & $5 \mathrm{~F}$ & 5'-AGGCCCTGCTTCTTTTTCTC-3' & \multirow[t]{2}{*}{254} & \multirow[t]{2}{*}{55.3} \\
\hline & $5 \mathrm{R}$ & 5'-AATCATTTGCAAGCAGCAAG-3' & & \\
\hline \multirow[t]{2}{*}{6} & $6 \mathrm{~F}$ & 5'-TGAATGAGTGCCAAGCAAAC-3' & \multirow[t]{2}{*}{277} & \multirow[t]{2}{*}{56.3} \\
\hline & $6 \mathrm{R}$ & 5'-TTCCCAAAACCCTACAGCAC-3' & & \\
\hline \multirow[t]{2}{*}{7} & $7 F$ & 5'-GAGTGACCAGTCTGCATCCC-3' & \multirow[t]{2}{*}{213} & \multirow[t]{2}{*}{59.1} \\
\hline & $7 R$ & 5'-TGGTTGCCATGTCAGGAAG-3' & & \\
\hline \multirow[t]{2}{*}{8} & $8 \mathrm{~F}$ & 5'-CTTCGAAGGTGTGGGTTTTG-3' & \multirow[t]{2}{*}{298} & \multirow[t]{2}{*}{57.3} \\
\hline & $8 R$ & 5'-TTCAGAGGATGAAACTCCCC-3' & & \\
\hline 9 & $9 \mathrm{~F}$ & 5'-GAGGCACTCTTGGTTCCATC-3' & 322 & 60.4 \\
\hline & 9R & 5'-CTGAGGCAGGAGGAGAGAAG-3' & & \\
\hline 10 & $10 \mathrm{~F}$ & 5'-CTTCTCTCCTCCTGCCTCAG-3' & 312 & 60.4 \\
\hline & 10R & 5'-GTTCCTGAAGCTCCTTCCTG-3' & & \\
\hline 11 & $11 \mathrm{~F}$ & 5'-ATTCTCTGTCCTCCCACCAG-3' & 195 & 60.2 \\
\hline & $11 R$ & 5'-GTCTGTCCTCCAGCCTGTG-3' & & \\
\hline 12 & $12 \mathrm{~F}$ & 5'-ATCAGCACGTGACCTCTCCT-3' & 271 & 57.4 \\
\hline & $12 R$ & 5'-CAACCAGTTTTCTGCGTTCA-3' & & \\
\hline 13 & $13 \mathrm{~F}$ & 5'-TTCCTTGCTGCCTGTTTAGG-3' & 257 & 58.3 \\
\hline & $13 R$ & 5'-TCAGCTATACCAGAAGATTCCAGA-3' & & \\
\hline 14 & $14 \mathrm{~F}$ & 5'-ATCTCGTTCCTGCCCTGACT-3' & 225 & 58.4 \\
\hline & 14R & 5'-GACACAGGACGCAGAAACAA-3' & & \\
\hline 15 & $15 \mathrm{~F}$ & 5'-CATTAGGCGCACACCTATGA-3' & 326 & 56.3 \\
\hline & $15 R$ & 5'-TCCATCTCGTGACCAAAATG-3' & & \\
\hline 16 & $16 \mathrm{~F}$ & 5'-TCTCGCAGACTTGGGAAGTT-3' & 277 & 59.2 \\
\hline & $16 R$ & 5'-GAGGTCACATAGCGGGAGG-3' & & \\
\hline 17 & $17 \mathrm{~F}$ & 5'-TTATGGTACGATGCCCGTGT-3' & 319 & 58.4 \\
\hline & 17R & 5'-GAGGATCATATGCCTCCAGC-3' & & \\
\hline 18 & $18 \mathrm{~A}: \mathrm{F}$ & 5'-GCTGGACTGATAGTTTCCGC-3' & 566 & 59.4 \\
\hline & $18 \mathrm{~A}: \mathrm{R}$ & 5'-CAAAGGCTAACCTGGCTGTC-3' & & \\
\hline 19 & $18 \mathrm{~B}: \mathrm{F}$ & 5'-GACAGCCAGGTTAGCCTTTG-3' & 467 & 57.4 \\
\hline & $18 \mathrm{~B}: \mathrm{R}$ & 5'-ATTCATTGACACGGGCTTTC-3' & & \\
\hline 20 & $18 \mathrm{C}: \mathrm{F}$ & 5'-TCTGTCGTGTGTGTTGGGAT-3' & 626 & 58.4 \\
\hline & $18 \mathrm{C}: \mathrm{R}$ & 5'-CCTGAGCTCAAACCATCCTC-3' & & \\
\hline 21 & $18 \mathrm{D}: \mathrm{F}$ & 5'-ATGGTGCATCAGCAGCC-3' & 558 & 57.3 \\
\hline & $18 \mathrm{D}: \mathrm{R}$ & 5'-TGTCTCTCCGGACATCAGTG-3' & & \\
\hline 22 & $18 \mathrm{E}: \mathrm{F}$ & 5'-ATCGTTTGACGGGACTTCAG-3' & 611 & 57.3 \\
\hline & $18 \mathrm{E}: \mathrm{R}$ & 5'-CAGAAGAACGTGCATCGAGT-3' & & \\
\hline
\end{tabular}

Exon specific intronic primers were designed (Table-1) to cover full length of exon (Reference Sequence: NC_000019.9), keeping the amplicon size 300bp to 500bp using Primer-3 (Bioinformatics tool). Overlapping primers were designed to exons which were more than $500 \mathrm{bp}$. All the designed primers were conformed through Insilico PCR (Bioinformatics tool) for the proper amplification and also confirmed in Genome Build 36 (Bioinformatics tool) for specificity of primer binding in genomic DNA. Primers were got synthesized by commercial oligo synthesizer (MWG Biotech, India). 
PCR amplification was carried out in a $20 \mu \mathrm{l}$ reaction volume containing $0.5 \mu \mathrm{l}$ of genomic DNA $(75 \mathrm{ng} / \mu \mathrm{l}$ to $150 \mathrm{ng} / \mu \mathrm{l}), 0.5 \mu \mathrm{l}$ of each primer (5pmol), $0.4 \mu \mathrm{l}$ of dNTP (10pmol), 0.2 $\mu \mathrm{l}$ Taq DNA polymerases (3units/ $\mu \mathrm{l}$ ), $4 \mu \mathrm{l}$ Taq Buffer (5X) (BioRad, USA) and total volume was adjusted to $20 \mu \mathrm{l}$ using molecular biology grade water. Amplification was carried out in Mastercycler gradient (Eppendorf, Germany) under the following conditions: an initial denaturation at $98^{\circ} \mathrm{C}$ for $10 \mathrm{sec}$, followed by 35 cycles at $98^{\circ} \mathrm{C}$ for $10 \mathrm{sec}$ (cycle denaturation), primer annealing temperature was set depending on the annealing temperature of each primer (Table-1) for $10 \mathrm{sec}, 72^{\circ} \mathrm{C}$ for $15 \mathrm{sec}$ (primer extension) and a final extension at $72^{\circ} \mathrm{C}$ for $5 \mathrm{~min} . \mathrm{PCR}$ products were confirmed for their respective amplicon size by gel electrophoresis with standard 100bp ladder.

PCR products were directly subjected to automated DNA sequencing (ABI_3500xl). Both forward and reverse reactions were carried out for all the samples and exons to minimize the machine made errors. Electropherograms were obtained and sequence alignment was carried out by DNA Baser (Bioinformatics tool).

\section{Results}

\subsection{Biochemical analysis}

The biochemical analysis results are shown in Figure-1, indicates high levels of serum LDL, triglycerides and total cholesterol. It was observed that, across the different age groups the levels remains almost similar.

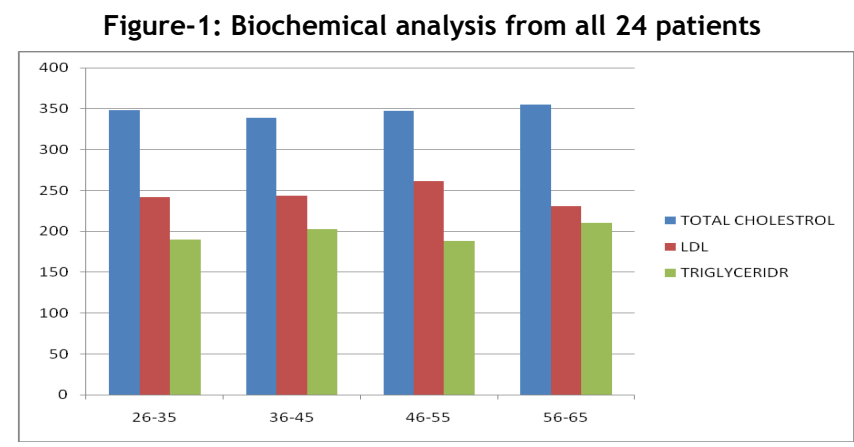

\subsection{Genetic analysis}

After sequencing all the 18 exons, three LDLR mutations were detected which were unique to the South Indian population and never been reported elsewhere ${ }^{9}$.Sequence analysis of the exon 3 showed a mutation at position 18298 from $A>C$ (g.18298A $>C$ ) (Fig-2) in patients $1,9,18,19$ and 20, which introduced a $\mathrm{Q}$ (Glutamine) in place of $\mathrm{K}($ Lysine) at amino acid position 69 (p.K69Q) in the reference sequence.

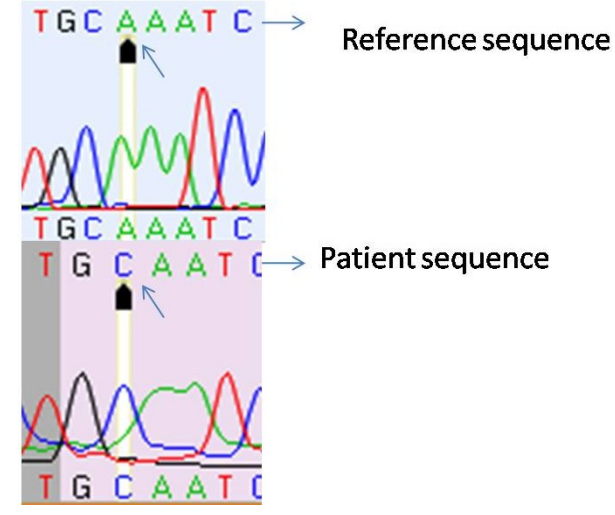

Figure-2: Showing $18298 \mathrm{~A}>\mathrm{C}$

In exon 10 we observed insertion $C$ between positions 29372 and 29373 (g.29372_29373insC) in all the 24 patients (Fig-3), which introduced a C (Cysteine) in place of $V$ (Valine) at aminoacid position 527 (p.V527C) in the reference sequence. At position 55, $A>G$ mutation (g.29209A $>G$ ) was found and it was predicted as silent mutation (Fig-4).

The sequence analysis of exon 3 and 10 from PCR products of control individuals not shown any of the said mutations (data not shown) according to the previously established studies. ${ }^{9}$

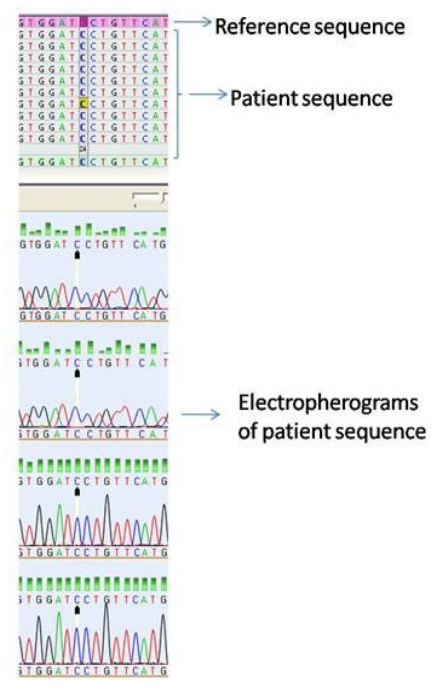

Figure-3:Showing insertion at g.29372_29373insC

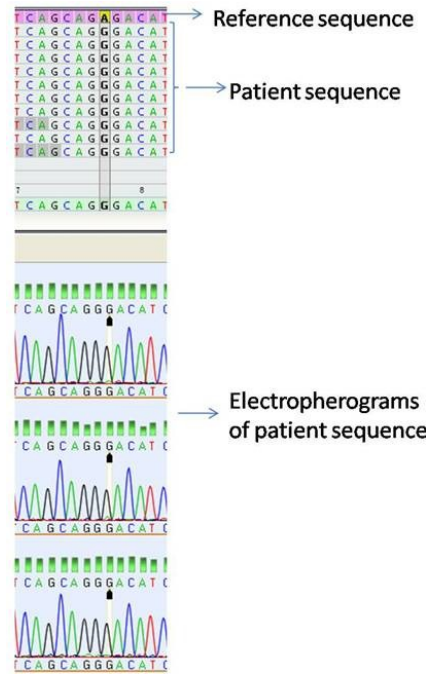

Figure-4:Showing g.29209A $>$ G

\section{Discussion}

More than 1,100 mutations have been reported in the LDLR gene in different populations. ${ }^{9-13}$ This gene is composed by 18 exons that encode a protein involving five domains: the ligand binding domain, the epidermal growth factor (EGF) precursor homology domain, the domain with $\mathrm{O}$-linked carbohydrates, the membrane spanning domain and the cytoplasmic part of the 
receptor. The ligand binding domain consists of seven repeats, each containing six cysteine residues, which form disulphide bonds within each repeat. ${ }^{14}$

All the three nucleotide changes reported here fulfilled the criteria of a mutation as these changes were not present in the controls. This is the first report of LDLR gene mutations in South Indian families. The mutations at position 18298 from $A>C$ (g.18298A $>C$ ) in exon 3 was found in patients $1,9,18,19$ and 20 who were clinically positive for Tendon xanthomas. It is predicted that, this missence mutation replaces K (Lysine) by Q (Glutamine) and hence change in the receptor protein structure of LDLR and thus leading to formation of Tendon xanthomas. A>G mutation (g.29209A $>G$ ) was found in exon 10 and was predicted as silent mutation. In all the 24 patients g.29372_29373insC was found in exon 10.This has introduced $C$ (Cysteine) in the place of $V$ (Valine) at p.V527C. The change in amino acid is predicted to cause structural changes in the LDLR protein and hence the receptor fails to bind with the ligand molecule (cholesterol). All the mutations and their corresponding effects on the protein were predicted computationally and was observed that these are responsible for changes in the structure of LDLR protein. Because of the change in the structure of the LDLR protein, it is unable to receive cholesterol molecules and transport inside the cell. Hence, cholesterol starts accumulating in the blood stream and leads to $\mathrm{FH}$.

India is known for high degree of inbreeding. This makes it necessary to screen a large number of patients perhaps within each group in order to get a true picture of contribution of LDLR gene mutation to $\mathrm{FH}$. Even though g.29372_29373insC was found in all the 24 patients, it makes necessary to screen large population to consider this as the biomarker considering frequency of the occurrence of $\mathrm{FH}$, in this regard efforts are going on in our laboratory.

\section{Conclusion}

In this study, we have reported three novel mutations in which one is silent and two are missence, which have never been reported in LDLR gene previously. The mutation g.29372_29373insC can be a potential biomarker after screening large population in India especially in South India. Once the biomarker is developed, it makes easy for the clinicians in the early diagnose of $\mathrm{FH}$ and make the treatment effective considering the cost, time and life of the patients.
Acknowledgements: We thank the University Grants Commission for providing the financial assistance for the project. We also thank the Government of Karnataka Department of Higher and Medical education for providing the infrastructure facility in the Research Center for DNA Diagnostics.

\section{References}

1. Goldstein JL, Brown MS. The LDL receptor locus and the genetics of familial hypercholesterolemia. Annu Rev Genet. 1979;13:259-89. http:// dx.doi.org/10.1146/annurev.ge.13.120179.001355 PMid:231932

2. Brown MS, Goldstein JL. A receptor-mediated pathway for cholesterol homeostasis. Science. 1986;232(4746):34-47. http://dx.doi.org/10.1126/ science. 3513311 PMid:3513311

3. Hobbs HH, Brown MS, Goldstein JL. Molecular genetics of the LDL receptor gene in familial hypercholesterolemia. Hum Mutat. 1992;1(6):44566. http://dx.doi.org/10.1002/humu.1380010602 PMid:1301956

4. Goldstein JL, Brown MS. Familial hypercholesterolemia. In: Scriver CR, Beaudet AL, Sly WS, Valle D (eds.). The metabolic basis of inherited disease, 6th ed. New York: McGraw Hill, 1989;1215-50.

5. Varret M, Rabes JP, Villeger L, Junien C, Beroud C \& Boileau C. Analysis of the 525 point mutation in the human LDL receptor gene database. Atherosclerosis, 1999; 144: 182-3 (Abstract). http:// dx.doi.org/10.1016/S0021-9150(99)80694-7

6. Soutar AK. Update on low density lipoprotein receptor mutations. Curr Opin Lipidol. 1998;9(2):141-7. http://dx.doi.org/10.1097/00041433-19980400000011PMid:9559272

7. Chaves FJ, Puig O, GarcÃa-Sogo M, Real J, Gil JV, Ascaso J, Carmena R, Armengod ME. Seven DNA polymorphisms in the LDL receptor gene: application to the study of familial hypercholesterolemia in Spain. Clin Genet. 1996;50(1):28-35.http:// dx.doi.org/10.1111/j.1399-0004.1996.tb02342.xl

8. Puig O, Chaves FJ, GarcÃa-Sogo M, Real J, Gil JV, Armengod ME. A three-allelic polymorphic system in exon 12 of the LDL receptor gene is highly informative for segregation analysis of familial hypercholesterolemia in the Spanish population. Clin Genet. 
1996;50(1):50-3. http://dx.doi.org/10.1111/j.1399-

0004.1996.tb02346.x

9. Fokkema IF, den Dunnen JT, Taschner PE. LOVD: easy creation of a locus-specific sequence variation database using an "LSDB-in-a-box" approach. Hum Mutat. 2005;26(2):63-8.http://dx.doi.org/10.1002/ humu.20201PMid:15977173

10. Leigh SE, Foster AH, Whittall RA, Hubbart CS, Humphries SE. Update and analysis of the University College London low density lipoprotein receptor familial hypercholesterolemia database. Ann Hum Genet. 2008; 72(Pt 4):485-98. Epub 2008 Mar 5. http://dx.doi.org/10.1111/j.14691809.2008.00436.xPMid:18325082

11. Varret M, Abifadel M, RabÃ"s JP, Boileau C. Genetic heterogeneity of autosomal dominant hypercholesterolemia. Clin Genet. 2008;73(1):1-13. Epub 2007 Nov 16. http://dx.doi.org/10.1111/j.13990004.2007.00915.xPMid:18028451

12. Zakharova FM, Damgaard D, Mandelshtam MY, Golubkov VI, Nissen PH, Nilsen GG, Stenderup A, Lipovetsky BM, Konstantinov VO, Denisenko AD, Vasilyev VB, Faergeman O. Familial hypercholesterolemia in St-Petersburg: the known and novel mutations found in the low density lipoprotein receptor gene in Russia. BMC Med Genet. 2005;6:6. http://dx.doi.org/10.1186/1471-2350-6-6

PMid:15701167 PMCid:551615

13. Callis M, Jansen S, Thiart R, de Villiers JN, Raal FJ, Kotze MJ. Mutation analysis in familial hypercholesterolemia patients of different ancestries: identification of three novel LDLR gene mutations. Mol Cell Probes. 1998;12(3):149-52. http:// dx.doi.org/10.1006/mcpr.1998.0164 PMid:9664576

14. Goldstein JL, Hobbs HH, Brown MS. Familial hypercholesterolemialn: Scriver CR, Beaudet AL, Sly WS, Valle D, editors. The Metabolic and Molecular Bases of Inherited Disease. 8th edition. New York, NY: McGraw-Hill; 2001. pp. 2863-913. 